\title{
IN MEMORIAM PROFESOR MICHAŁ ŁESIÓW (3.05.1928 - 15.07.2016)
}

\author{
MATEUSz JASTRZĘBSKI \\ Uniwersytet Marii Curie-Skłodowskiej w Lublinie
}

W dniu 15 lipca 2016 roku odszedł od nas prof. dr hab. Michał Łesiów - znakomity naukowiec, świetny nauczyciel akademicki, wychowawca kilku pokoleń młodych ludzi, a nade wszystko niezwykle ciepły człowiek porozumienia i dialogu, zwłaszcza dialogu polsko-ukraińskiego.

Profesor Michał Łesiów był od ponad 6o lat nierozerwalnie związany z Lublinem i dwoma lubelskim uniwersytetami - Uniwersytetem Marii Curie-Skłodowskiej i Katolickim Uniwersytetem Lubelskim. Przez wiele lat współpracował także z Wyższym Seminarium Duchownym w Lublinie, prowadząc tam zajęcia dla kleryków wyznania greckokatolickiego. W Lublinie podjął w 1950 roku studia na filologii polskiej KUL, które ukończył w 1955 roku. Po rocznym pobycie na stażu naukowym w Instytucie Językoznawstwa PAN w Krakowie powraca do Lublina w 1956 roku, by rozpocząć pracę w Katedrze Języka Polskiego UMCS. Od tego momentu, przez 52 lata, jest nieprzerwanie związany z tą lubelską uczelnią, pełniąc różne funkcje - kierownika Zakładu Filologii Rosyjskiej (później Zakładu Języka Rosyjskiego oraz Zakładu Filologii Ukraińskiej), dyrektora Instytutu Filologii Rosyjskiej i Słowiańskiej oraz Dziekana Wydziału Humanistycznego (w latach 1981-1984).

Profesor Michał Łesiów urodził się 3 maja 1928 roku we wsi Huta Stara w powiecie buczackim na Tarnopolszczyźnie. Tu uczęszczał do miejscowej szkoły podstawowej, gdzie uczył się do roku 1941. Po II wojnie światowej rodzina Profesora skorzystała z możliwości repatriacji i przesiedliła się do wsi Zielin w byłym województwie szczecińskim. Tu Pan Profesor kontynuował naukę, zdobywając tzw. mała maturę w Gryfinie (1948 r.) oraz dwie duże matury (1950 r.) - w Niższym Seminarium Duchownym w Gorzowie Wielkopolskim oraz maturę państwową, uzyskaną na podstawie zdanych egzaminów w Kuratorium Szczecińskiego Okręgu Szkolnego. 
Po ukończeniu szkoły średniej rozpoczął naukę na Katolickim Uniwersytecie Lubelskim, początkowo na Wydziale Filozofii Chrześcijańskiej, a następnie na filologii polskiej. W 1955 roku uzyskał tytuł magistra filologii polskiej na podstawie pracy magisterskiej na temat Opis gwary mieszkańców wsi Huty Starej w powiecie buczackim, napisanej pod kierunkiem prof. Tadeusz Brajerskiego.

Bezpośrednio po ukończeniu studiów mgr Michał Łesiów odbył roczny staż naukowy w Instytucie Językoznawstwa PAN w Krakowie pod kierunkiem prof. Kazimierza Nitscha.

W 1956 roku powrócił do Lublina i podjął pracę w Katedrze Języka Polskiego UMCS, którą kierował wtedy profesor Leon Kaczmarek. Szybko włączył się w życie naukowe, uczestnicząc w zbieraniu materiału toponomastycznego oraz w przygotowaniu Atlasu gwar Lubelszczyzny. W 1960 roku odbył roczny staż naukowy w Uniwersytecie Tarasa Szewczenki w Kijowie. Profesor uzyskał stopień doktora (w 1962 roku) na Wydziale Filologicznym Uniwersytetu Warszawskiego na podstawie rozprawy Język dramatów zachodnioukraińskich XVII - początku XVIII wieku, przygotowanej pod kierunkiem prof. Leona Kaczmarka.

W roku 1963 został przeniesiony z polonistyki do tworzącego się Zakładu Filologii Rosyjskiej jako jeden z jej organizatorów. W roku 1969 wówczas doktor Michał Łesiów otrzymał stanowisko docenta etatowego. Rok później został kierownikiem Zakładu Filologii Rosyjskiej UMCS, a następnie (w 1973 roku) dyrektorem Instytutu Filologii Rosyjskiej i Słowiańskiej UMCS. W tym roku uzyskał również stopień naukowy doktora habilitowanego na podstawie monografii Terenowe nazwy własne Lubelszczyzny.

W 1973 roku Profesor Michał Łesiów przebywał na Uniwersytecie Harvarda w Cambridge (Mass.), gdzie prowadził zajęcia w zakresie językoznawstwa słowiańskiego, a zwłaszcza ukraińskiego. Ponownie do Stanów Zjednoczonych wyjechał jeszcze w 1986 roku, gdzie pracował jako visiting professor w Uniwersytecie Minnesockim w Minneapolis.

W 1981 roku Michał Łesiów został wybrany Dziekanem Wydziału Humanistycznego UMCS, co było wyrazem uznania i szczególnego zaufania ze strony macierzystego środowiska uczelnianego. Okres kadencji przypadł na czas trudny - strajków studenckich, stanu wojennego, zawieszenia zajęć na uczelni, - który, jak przyznaje Jubilat, udało się nam przeżyć bez szwanku moralnego.

W roku 1983 docent Michał Łesiów otrzymał tytuł profesora.

Po zmianie sytuacji politycznej i ogłoszeniu niepodległości przez Ukrainę władze UMCS, za zgodą Senatu, powołały w 1991 roku studia w zakresie filologii ukraińskiej oraz utworzyły Zakład Filologii Ukraińskiej, a jego kierownictwo powierzono Profesorowi Michałowi Łesiowowi. Decyzja ta była urzeczywistnieniem się wieloletnich starań 
i spełnieniem marzeń Profesora. Kierownikiem Zakładu Filologii Ukraińskiej UMCS pozostawał Profesor Michał Łesiów do przejścia na emeryturę w 1998 roku.

Pomimo nowych, licznych obowiązków, związanych z organizacją nowej jednostki, Profesor zawsze znajdował czas na działalność naukową. W 1997 roku ukazuje się monografia Украӥнські говірки в Польщі (Gwary ukraińskie w Polsce), która dokładnie opisuje 6 dialektów ukraińskich, występujących na terenie Polski. Profesor Michał Łesiów pozostawał nieobojętny również na potrzeby dydaktyczne placówek oświatowych z ukraińskim językiem nauczania. W 1996 roku ukazuje się drukiem jego podręcznik do gramatyki języka ukraińskiego pt. Шкільна граматика української мови. Pо przejściu na emeryturę nie zaprzestaje pracy naukowej. Zaowocowało to następującymi publikacjami: O Ukrainie. Prawie wszystko!? (wsp., 2011), Recensio. Про прочитані книжки та їх авторів (2012), Мої мовні поради (2015), Українська літературна мова XVII XVIII століть. Зібрані праці (2016), Literatura chtopska w powojennej Polsce. Prace zebrane (w druku: 2017).

Wspomnieć należy także o działalności dydaktycznej Profesora Michała Łesiowa. Był on promotorem ponad 6oo prac magisterskich z zakresu językoznawstwa rusycystycznego, ukrainistycznego, białorutenistycznego i polonistycznego. Swoją znaczącą cegiełkę dołożył również do rozwoju młodej kadry naukowej. Wypromował 21 doktorów, recenzował około 50 rozpraw doktorskich, które powstawały w wielu ośrodkach uniwersyteckich Polski oraz opiniował w ponad 20 przewodach habilitacyjnych i kilkunastu postępowaniach o awanse profesorskie.

Istotne miejsce w pracy Profesora Michała Łesiowa zajmowała działalność popularyzatorska. Szczególnym zainteresowaniem dużej rzeszy słuchaczy cieszyły się Wykłady Ogólnouniwersyteckie - Ukraina wczoraj i dziś oraz Rola kulturotwórcza Ukraińskiej Cerkwi Greckokatolickiej. Zostały opublikowane w serii Wykłady otwarte UMCS i cieszyły się na tyle dużym zainteresowaniem czytelników, że doczekały się drugiego wydania. Profesor był autorem popularnego cyklu porad językowych (Мовні поради), drukowanych przez kilka lat w tygodniku mniejszości ukraińskiej Nasze Słowo. Na jego łamach bardzo często zabierał głos w wielu istotnych sprawach, które dotyczyły społeczności ukraińskiej w Polsce.

Działalność naukowa, dydaktyczna i organizacyjna Profesora Michała Łesiowa była wielokrotnie doceniana w środowisku, czego dowodem są liczne nagrody i wyróżnienia - Złoty Krzyż Zasługi, Krzyż Kawalerski Orderu Odrodzenia Polski, Krzyż Oficerski Orderu Odrodzenia Polski, Medal Komisji Edukacji Narodowej, odznaczenie Memoria Iustorum. Szczególne znaczenie dla Profesora miał medal Pro Ecclesia et Pontifice, przyznany Mu przez Papieża Jana Pawła II. Profesor był także członkiem wielu organizacji naukowych i społecznych oraz komitetów redakcyjnych. 